\begin{tabular}{|c|c|}
\hline DOSSIER & $\begin{array}{l}\text { ONE SUB ECT, MANY PA' } \\
\text { transmedia communication in } \\
\text { journalism }\end{array}$ \\
\hline $\begin{array}{r}\text { Copyright @ } 2012 \\
\text { SBPjor / Associação } \\
\text { Brasileira de } \\
\text { Pesquisadores em } \\
\text { Jornalismo }\end{array}$ & $\begin{array}{l}\text { ANDRÉ FAGUNDES PASE } \\
\text { Pontifícia Universidade Católica do Rio Grande do Sul, Brazil } \\
\text { ANA CECÍLIA BISSO NUNES } \\
\text { Pontifícia Universidade Católica do Rio Grande do Sul, Brazil } \\
\text { MARCELO CRISPIM DA FONTOURA } \\
\text { Pontifícia Universidade Católica do Rio Grande do Sul, Brazil }\end{array}$ \\
\hline
\end{tabular}

\begin{abstract}
Transmedia communication is used mainly in fiction, but also in journalism. This paper analyzes the informational synergy of transmedia in the news field. Through a conceptual digression, we discuss the word transmedia, as defined by Jenkins (2006), cross-media and multimedia, explaining the differences between all those concepts - sometimes treated by some authors as synonyms, although they are not. The ideas are revisited and verified through the study of Inside Disaster, a Canadian documentary about the 2010 Haitian earthquake that offers news by means of game, hypertext and video. Above all, we propose a reflection on the implications of the transmedia experience applied to journalism, a look at transmedia communication thinking not only about technology, but searching for a cultural and social interpretation, in a cultural perspective of the study of technology and journalism.
\end{abstract}

Keywords: Transmedia. Convergence. Journalism. Documentary. Haiti.

\title{
UM TEMA E MUITOS CAMINHOS a comunicação transmidiática no jornalismo
}

RESUMO - A comunicação transmidiática é utilizada sobretudo na ficção, mas também no jornalismo. Este artigo analisa tal sinergia informacional no campo das notícias. Por meio de uma digressão conceitual, discutimos os termos transmídia cunhado por Jenkins (2009), cross-media e multimídia, estabelecendo as diferenças de conceitos que ainda são tratados como sinônimos por alguns autores, mas não o são. Os conceitos são resgatados e verificados em suas aplicações no caso Inside Disaster, um documentário canadense sobre o terremoto haitiano de 2010, que oferece notícias em jogos, hipertextos e vídeos. Acima de tudo, propomos uma reflexão sobre as implicações da experiência transmidiática aplicada ao jornalismo, um olhar para a comunicação transmídia perpassando não apenas os suportes, mas buscando um viés cultural e interligado com as sociedades, em uma perspectiva culturalista do estudo da tecnologia e do jornalismo.

Palavras-chave: Transmídia. Convergência. Jornalismo. Documentário. Haiti. 


\section{INTRODUCTION}

Convergence refers to a context, a scenario of transformation in different spheres, which responds to an essentially cultural demand and blurs several frontiers, even the ones associated with journalism. As a product of a collective demand for the cognitive interconnection of content, convergence transforms the relation between individuals and information and the very nexus of building and assimilating content. It is a context materialized in the convergence of media platforms, but driven by cultural practices. We have never been passive receivers of information. We are becoming each time more migratory, concerning the choice of information and cognitive ways to build knowledge. We are interagents' (PRIMO, 2003).

The context of convergence culture sees the rise of transmedia storytelling, but first in the entertainment field. As Jenkins (2006, p. 21 ), states, it "refers to a new aesthetic that has emerged in response to media convergence - one that places new demands on consumers and depends on the active participation of knowledge communities". This initiative, with Hollywood origins, is being transposed to journalism. Transmedia is created through the deconstruction of a structured model of information dissemination, becoming a both singular and important phenomenon, especially to journalism. The informational synergy, typical of convergence, highlights the need for renovation in the journalistic field.

We propose the discussion of transmedia in its cultural and political meaning in journalistic activity and in the process of assimilating news content, reflecting about its relation with society and its consequences. We deliberate on the term, coined by Jenkins (2006), and collate it with the concepts of cross-media, multimedia and convergence, with the goal of starting a theoretical debate, but which has of sociocultural roots and consequences. This approach is applied to a case study of transmedia journalism. The documentary Inside Disaster invites interagents to undergo a cognitive immersion in the Haitian earthquake of 2010 and stimulates critical thought in the face of those events. The research demonstrates that transmedia storytelling, despite contradicting the formula composed of deadline, market and cost, is consistent with the effort to achieve a critical and emancipatory journalism, in dialogue with the very purpose of the profession.

\section{Convergence Culture}

Technological changes are related not only to technical issues, 
but mainly to utilizations, to culture and to society as a whole. The root of the transformation occurs when people utilize technologies and give them a meaning, a utility, a symbolic and material importance. New media and narrative languages are part of a process that dialogues with social and cultural matters. We assume that this convergent process of languages and media should be faced in a broad way. Jenkins (2011) portrays the convergence scenario as an extensive one that modifies the relation between audience and media in a general way: "[...] a paradigm for thinking about the current moment of media change, one which is defined through the layering, diversification, and interconnectivity of media". Thus, a "new" media does not replace an "old" one, but there are adaptations and new uses by the public, whose character is also different. An immersive reader arises, "connecting knots and nexus, in a multi-linear, multi-sequential and labyrinthine script, which he himself helped to build" (SANTAELLA, 2007, p. 33). The audience has found ways of showing its singularity and building its own paths of content assimilation.

The audience changes its relation with platforms, content and narratives. It does not want to be just a spectator of the process anymore, but part of it (JENKINS, 2006). And, opposed to the "technicist myopia, which values the interaction between man and machine, more than the dialogue man-man, mediated technologically" (PRIMO, 2003, p. 131), we call this connected individual, typical of the convergence culture, "interagent" (PRIMO, 2003, p. 131). In other words, someone who utilizes technologies, gives them a meaning and is active in the process of cognitive building of content. For Jenkins (2006), it is an audience that is not afraid to migrate and dialogues with the changes.

Concerning journalism, Deuze (2009) states that the public is skeptical regarding the origins of information, resulting in the use of channels of participation both official and informal, as a permanent counterpoint to what is reported. We see the rise of a globalized and at the same time, a critical citizen, but with degrees of disbelief in traditional institutions, including the traditional mass media (DEUZE, 2009). This is the starting point for several cultural and media transformations.

Transmedia storytelling finds itself in a constant dialogue with the perspective of unique and individual building of content, of the choice of paths between multiple possibilities and of the emergence of this globalized citizen. Shirky (2009, p. 160) highlights: "revolution doesn't happen when society adopts new technologies. It happens when society adopts new behaviors". We adopt new behaviors when facing 
content in new paths. Society demands transformations in journalism.

\section{Transmedia and cross-media and multimedia narratives in the convergence culture}

In synchrony with this cultural and social scenario, new ways of narrating content appear, as well as new denominations for those narratives. Before analyzing Inside Disaster, it is essential to distinguish those concepts and understand their peculiarities, in order to delimit what transmedia storytelling really is today.

The set of terms transmedia, multimedia, cross-media and convergence causes confusion. The concept of "transmedia" is explained more deeply in a chapter of the book Convergence Culture (JENKINS, 2006). The work became a synonym of the expression, although it represents much more than just a delimitation of nomenclature.

The idea of transmedia is connected with society. As Jenkins (2011) states, it is mistaken to relate transmedia to the simple interchange between media platforms. The expression is linked to the relations of the audience with technology and information.

\footnotetext{
I have been troubled by writers who want to reduce transmedia to the idea of multiple media platforms without digging more deeply into the logical relations between those media extensions. [...] As we think about defining transmedia, then, we need to come back to the relations between media and not simply count the number of the media platforms (JENKINS, 2011).
}

Transmedia dialogues with a larger cultural process which materializes the plural relations between different ways of assimilating content, heterogenic audiences and the media themselves.

Certain processes integrating content in different platforms, as well as the intention to link narratives in diverse media precede the Internet. The possibility of a company acting in several media platforms at the same time already made it possible to have references between the contents of one platform and another. The same story, told in multiple media.

What we see today is different. We are not thinking about just referring contents, but about a narrative which can only be made whole by all of its parts together. Each individual chooses which ones of them will make up part of his narrative, but that story will only be complete by seeking the largest possible number of parts. They are like pieces of a jigsaw puzzle: some form the central picture, some are on the edges, but, to for a complete picture, each piece is important. In transmedia storytelling, those parts can appear every day. "More and 
more, storytelling has become the art of building universes [...]. The universe is larger than the film, larger even than the franchise, since fans' speculations and elaborations also expand the universe in various directions" (JENKINS, 2006, p. 114). It is therefore a product of segmented narratives, disseminated in different, multiple channels of direct communication with the audience. There is a main story, in harmony with other shorter ones; each part of the whole is told in its own way.

The idea of cross-media is present in several transmedia initiatives, and is related to the marketing field.

\footnotetext{
Marketers use the term cross-media promotion to describe any promotional campaign that uses more than one medium. There is nothing new in the promotion of trademarks by means of more than one medium. The term, cross-media promotion, however, is used by marketers to refer to a planned promotion strategy in which multiple media are used to promote a product or service (HARDY, 2010, p. 3).
}

The definition can be applied to journalism. Different media and/or platforms are used to divulge or relate a story or subject. This use, as mentioned, was not born now. Although many times crossmedia is the link between transmedia processes (when one part sends to others that compose the whole), they are not synonymous. It is a practice that transcends journalism, permeates marketing and only refers to the relationship between platforms, but not to the process of complementation of transmedia narratives, which constitutes transmedia.

The concept of multimedia communication also has its borders with transmedia erroneously blurred sometimes. Both are characterized by the platform used. The difference lies in the content: in transmedia, narratives are complementary; in multimedia, content is similar or very close, not complementary. As stated by Negroponte (1996, p 70.), "thinking about multimedia implies having an idea of the fluid movement from one medium to the next, saying the same thing in different ways, calling upon one human sense or another." Multimedia is carried out in several media, but is not necessarily convergent, or cross-media.

Convergence is runs through all these terms. It characterizes a context. "Convergence represents a cultural shift to the extent that consumers are encouraged to seek out new information and make connections amidst dispersed media content." (JENKINS, 2006, p. 3) Proactivity in seeking information delineates, among other factors, the convergence culture. The culture of each place affects convergence in the way it reveals itself (if materialized) in a given society. Quinn (2005) 
states that it differs from country to country, within the country, and even in smaller places such as on the corporate level.

Journalism has gone through experiences of acting (in an integrated way or not) in different media, mainly through large media groups, with the proper structure for doing it. However, a truly transmedia journalism needs to be thought of this way from the start. This intense planning and the demand for time and resources make it very difficult to implement transmedia storytelling in daily journalism, as emphasized by Moloney (201 1, p. 12): "Daily journalism, with its time-constrained brevity, is not a viable option. Transmedia narratives must be designed carefully and developed with a lengthy lead time to be effective". Due to this, there are various examples of multimedia journalism in daily journalism, in which subjects are narrated in a disperse manner by multiple platforms, as in the cases of news of corruption, tragedies or even coverage of sports or elections. However, returning to the definitions presented, it is important to emphasize that the lack of planning makes it impossible to perfect the complementary nature of the contents, essential in transmedia, making them reproductions of similar contents in different languages. This is a multimedia coverage, but not transmedia..

For Moloney (2011), the perfect place for this kind of coverage is formed by extensive and complex issues, which involve several viewpoints, origins and consequences. "Coverage of a complex and ongoing issue - immigration, the aftermath of war, social struggle lends itself perfectly to a considered approach and complex delivery" (MOLONEY, 2011, p. 12). Transmedia is larger than the 24 hour cycle of daily journalism, or the immediacy of online or audiovisual publications. It can be inserted in daily journalism, but its production necessarily follows a cycle of its own, not connected to the 24 hour one, and due to its enduring theme, following a standard pattern both for production and distribution far beyond the daily cycle.

Meanwhile, combining transmedia narrative with journalistic work (even though it differs from the immediacy or agility typical of traditional journalism) is an extremely important opportunity to bring information in a different way to the public and to immerse it in another "universe", as well as encouraging critical thinking. For Moloney (2011, p. 12), "journalists have always hoped to be not only educational, but also powerfully resonant and interesting to their public." The author emphasizes that transmedia has the potential to leverage (by means of its many facets) the audience's engagement in the news.

With its peculiarities and divergences from the prevailing 
practice of commercial mass journalism, transmedia provokes important reflections about what is considered to be the essence of the activity. When talking about transmedia storytelling, its feasibility in daily journalism is often discussed. However, it is more important to think of it in a dialogue with the very purpose and the social role of journalism than in its relation to temporal logics, which are culturally and commercially established. Journalism is not, and never was, only daily. The logic of journalism is more related to information and the construction of a people's citizenship. Transmedia instigates a deconstruction of everyday journalistic practices that focus on time, in favor of a journalism that dialogues with the essence of the activity and is less tied to the logic of immediacy, but not disconnected from the logic of contemporary capitalist societies. Although it follows its own logic, transmedia can be inserted into online, television, or even print daily newsrooms, but the logic of production and distribution of this content must respect its peculiarities. The same thing happens when games are produced with journalistic subjects (newsgames) and placed in newsrooms that race against the clock. An example is the G1 news portal (http://gl.globo. com) that has developed several initiatives like these recently: the games have a production logic beyond immediacy, but are inserted in a news portal that has immediacy as its identity.

\section{Inside Disaster}

Developed in 2010 by PTV Productions in partnership with the Canadian government, Inside Disaster is a transmedia documentary about the earthquake that struck Haiti in January, 2010. It is a successful initiative and received several awards, such as the Applied Arts Interactive Award 2011 , and was one of the highlights in the Cames 4 Change 2011 competition. It was also nominated for the Webby Awards 2011 and New Media Awards (INSIDE DISASTER, 2010b).

The documentary is based on three main pillars - all interconnected - that tell stories that take place in Haiti and try to reproduce the post-disaster reality of the country. One of the pillars is a television documentary. Composed of three parts - Emergency, Relief and Recovery, Help and Recovery, each lasting 45 minutes (INSIDE DISASTER, 2010a), it details the post-tragedy Haitian scenario in a linear and audiovisual form. Another part of the project is composed by the data that appears on the website of Inside Disaster. There are several interactive graphics that offer extensive information about the earthquake and humanitarian work in Haiti. The fifteen articles, each one 
addressing an aspect of the scenario, are divided into three areas (INSIDE DISASTER, 2010c): the Quake, Response and Recovery.

The third - and most disruptive - segment of Inside Disaster is the simulator Inside the Haiti Earthquake. As the website states, it is a "[...] a first-person simulation based on documentary footage from Haiti and real-life decision scenarios" (INSIDE DISASTER, $2010 \mathrm{~b})$. The page invites the reader to experience: "What decisions would you make as an earthquake survivor, aid worker, or journalist in Haiti after the earthquake?"

\section{Inside Disaster as transmedia journalism}

As a transmedia initiative, Inside Disaster is a puzzle with many, but still measurable, parts, grouped into three segments that compose the main narrative. The individual cognitive intersection between different segments of this story is a choice of each user, but the three parts are related to each other in a planned manner to form a cohesive and complete story. One notes the minutely articulated work of the construction of these cognitive intersections that appear to the interagent in a natural way. Returning to the question: unlike the hard news - from day to day - a transmedia narrative is based on the deconstruction of a linear reasoning and the production logic of traditional journalism, is which time is the enemy of the journalist. More attention is given to the content and experience, rather than to standardized and uniform news. However, the main trump card of transmedia is also an obstacle. There lies the challenge of the expansion of transmedia communication within the newsrooms of major media groups: the triad composed of time, market and cost.

The question, then, is discovering how to place these barriers in a dialogue with the benefits of a transmedia narrative for news dissemination. As Jenkins (2011) states, a structure of transmedia content must satisfy at least one of these requirements:

- Offers backstory;

- Maps the World;

- Offers us other character's perspectives on the action;

- Deepens audience engagement.

Inside Disaster has these four characteristics. The combination of the video documentary, the simulator and the database published on the website maps the world of post-disaster Haiti. As Davidson 
(2008) interprets, transmedia stories are narrated in a way to take advantage of the best characteristic each medium has to offer. Inside Disaster articulates this informational synergy in order to make the storyline immersive and critical. The simulator adds the perspective of several characters, and invites the audience to participate by making decisions. The background of this story depends on the path chosen by the interagent: for those who favor the articles of the site, the background becomes the simulator and the television documentary, but the reverse also applies. Consistent with the characteristics compiled by Jenkins referring to transmedia, there is no doubt that Inside Disaster is a representative of transmedia journalism. We emphasize that Jenkins worked with the concept thinking of entertainment, although he does not ignore the possibility of its use by other industries.

With respect to journalism, the analysis of this project shows that this type of narrative can enhance the social function of the profession that has been losing ground with the constant marketization of information throughout its history: the development of informed and critical citizens.

Journalism, as a result [according to Habermas ' thinking about the public sphere], was charged with the crucial role of ensuring that these individuals were able to draw upon a diverse spectrum of information sources to sustain their views, a responsibility which placed it at the center of public life (ALLAN, 1997, p. 300).

Inside Disaster, representing transmedia storytelling, invites the interagents to take a critical view of the tragedy, of the data a nd the scenarios presented, since they are impelled to make decisions. It requests the interagents to think critically about the subject, putting themselves in the chosen character's place. This approach proposes projecting the interagents with relation to the characters, a difficult task to be implemented in such an incisive way in a traditional, informative report (written, televised or other forms).

But this invitation is based in a journalism model that breaks away from the traditional Brazilian standards of supposed neutrality, and lies closer to the American standards of critical, opinionative journalism. As a journalistic narrative the project resembles an editorial, or a column expressing an opinion, more than a supposedly neutral descriptive news report. Every character's mission shows the position of the documentary: the journalist (sent especially to the place) should try to tell the story beyond what is being said by the other professionals; the survivor, in addition to carrying on, should 
help other citizens in need; and the aid worker should assist people through his NGO, in the most effective way possible. If, on one hand, the specific missions encourage the citizens to take a humanitarian view, on the other hand they are also linked to an idealized nature of the roles of those characters, moving towards a utopian image.

The simulator is a newsgame, and it is part of a transmedia narrative. In the definition of Gonzalo Frasca, known as one of the first to use the expression:

Newsgaming is a word we coined for describing a genre that is currently emerging: videogames based on news events. Traditionally, videogames have focused on fantasy rather than reality, but we believe that they can be a great tool for better understanding our world. (NEWSGAMING.COM, 2003)

Continuing on the simulator, the critical view reappears ${ }^{2}$ : one should make decisions to follow the story and try to succeed in it. Concerning the opinionative nature of the game, besides the missions of the characters it is possible to identify the inclination of Inside Disaster, since only one choice, one option of each character leads to the "happy ending". Thus, when we prepare a flowchart of each character's path in the game, we can see that each one has a dilemma, which is a decisive and crucial point for his final fate.

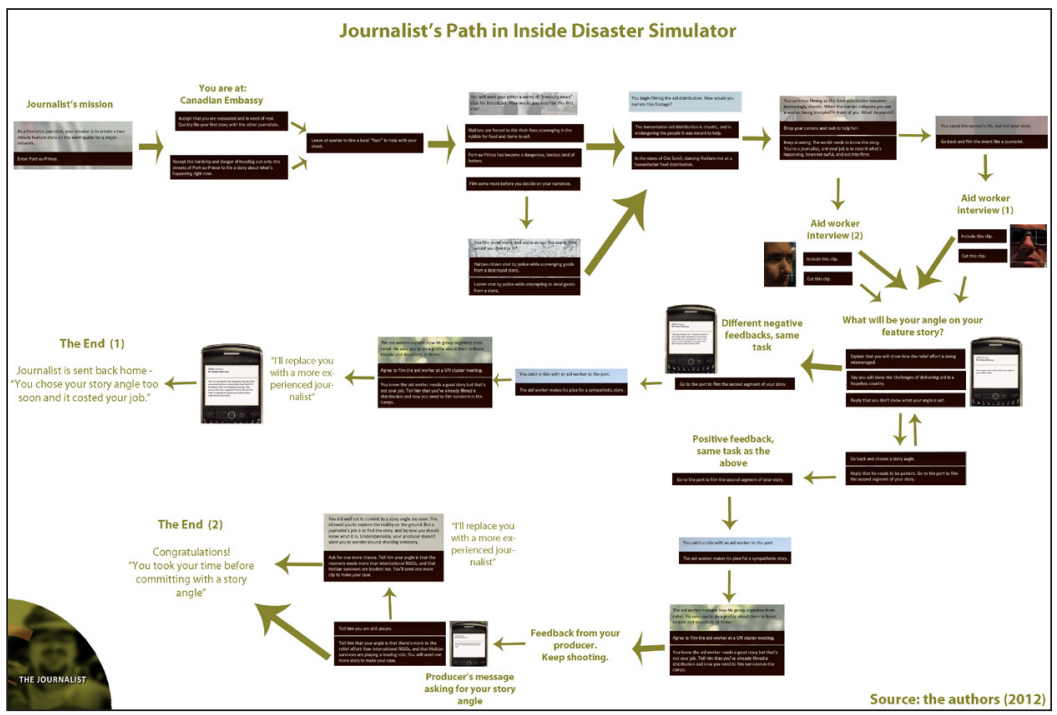

Source: Elaborated by the authors

In the case of the journalist, this decision point is the choice of the angle of his reporting. This professional's simulator criticizes 
the pressure of time prejudicing the quality of the story. The reporter will only achieve his goal if he looks for good information and does not give in to the pressure of the market, a common dilemma in the field. The survivor, in turn, has the challenge of enduring his suffering and difficulties, carrying on with hope and solidarity with his fellow Haitians in need, without giving up. Finally, the aid worker must make a decision of equal importance: follow the recommendation of the Red Cross for planning the distribution of food and carry it out, or help on his own, more quickly. Non-planned donations lead to violence, confusion and bad distribution of food to the people.

Beyond these factors lies the constant alternation between fiction and reality proposed by the Inside Disaster. Although the course on the simulator is fictitious, the images are real, obtained in Haiti in the postdisaster period, and used in the video documentary. The spectator who has watched or interacted with all the pillars of Inside Disaster will have a broad news experience. He can contrast this virtual experience with the data of the website and even with information beyond Inside Disaster. This data from other areas has the potential to change his course on the simulator, according to the data he obtained and assimilated previously. The cognitive knots and nexus are built by the interagent, in a process of constant dialogue with the convergence culture.

\section{Conclusions}

As an example of transmedia journalism, Inside Disaster shows that transmedia narratives have the potential to amplify the news experience, appealing to more than one sense for the assimilation of content, and disrupting a non-connected model of information utilization. This model is not vulnerable to the limitations of a traditional media platform (print, television, radio etc.), and uses the potential of the new technologies and social and cultural demands, in order to achieve a unique journalistic experience.

But the consequences of transmedia experience for established journalism go beyond the recombination of languages, dialoguing with issues of the activity's essence. Kovach and Rosenstiel (2007, p. 12) recall that the function of journalism has been the same down through the years, regardless of technical or language changes: "the primary purpose of journalism is to provide citizens with the information they need to be free and self-governing".

Transmedia is an immersive experience that invites people to assume a critical positioning and puts in question impartiality and 
instantaneity, but it also means the strengthening of a conscientious journalism. It provides a critical approach of the subject, making possible an entire diversity of media literacy. This approach encourages the interagent to be more critical with regard to the facts, mainly those facts having some relation to the narrative's subject. Each opinion and each decision will influence the form of development of the story. This look tends to extend to other moments, with the interagent trying, in other stories (even without a clear incentive for this), to build his own knots and nexus, to also take a critical stand in this other moment. It is a literacy process. A critical story allows the reader to open his universe, so he can be more and more critical of the facts and seek, through his knots and nexus, assistance to reflect critically.

This form of utilization of content proposed by Inside Disaster allows the creation of "points of media contact" (JENKINS, 2006). This points, despite being pre-planned, lead to individual utilizations of content, in accordance with the recombination of the resources performed by each one. On the simulator, the experience and the ending (both positive and negative) lead to a critical tension between the paradigms proposed by the game and the interagent's principles, encouraging the interagent to reflect on both viewpoints, if they are different. Moloney (2011, p. 103) states: "by making our work more immersive and providing ways for our publics to take our stories into their personal lives and act on them, we better achieve our nearly universal goal of fostering positive social change".

The experience of convergence and transmedia also shows that it is not possible to regard journalists as mere stenographers, only transcribing their sources. One should not forget that those professionals help to form opinions. In the logic of production, transmedia deals with issues rooted in contemporary journalism, with its production and distribution dependent upon the deconstruction of instantaneity, and demonstrating the benefits of reporting with plenty of time to be developed. Hard news is part of journalism and fulfils its social role, but the activity should not be limited to the time factor.

We believe the path to a more engaged society points to the formation of more critical citizens. Transmedia narratives, mainly those using newsgames among their items, are resources for stimulating the taking of positions by interagents on political and social issues, as well as decision making. There is an emancipating power in those narrative structures, whose benefits for society are deeper than just showing a story from more than one side. 


\section{NOTAS}

1 We use the designation "interagent", from Primo (2003), to refer to the information consumer of the convergence culture, who is both active and interactive in the search for information in different channels of communication, building his own narrative. For Primo (2003, p. 133), the term "originates the idea of interaction [...]. Interagent because he is the one interacting with others".

2 Our intention here is to distinguish the incentive to critical thinking when the newsgame encourages the interagent to think about reality and choose a position - from the opinion of the game itself (its opinionative character), which certainly incentives a positioning, but also directs it. We find the first attitude completely connected to the social function of journalism, to form critical citizens. The second is opinionative and linked to an opinion-based journalism (not that this makes it less legitimate).

\section{REFERENCES}

ALLAN, Stuart. News and the public sphere: towards a history of objectivity and impartiality. In: BROMLEY, Michael; O'MALLEY, Tom (Org.). A Journalism Reader. London: Routledge, 1997. p. 296-329.

BOLTER, Jay David; GRUSIN, Richard. Remediation: Understanding New Media. Cambridge: The MIT Press, 2000. 307 p.

DAVIDSON, Andrew. Stories in Between: Narratives and Mediums@ Play. Halifax: ETC Press, 2008. 194 p.

DEUZE, Mark. The future of citizen journalism. In: ALLAN, Stuart; THORSEN, Einar (Org.) Citizen journalism: global perspectives. 1 ed. New Jork: Peter Lang, 2009. p. 255-264.

HARDY, Jonathan. Cross-media Promotion. New York City: Peter Lang, 2010. 352 p.

INSIDE DISASTER. Inside the Documentary. About the Documentary. Toronto, 2010a. Available at: <http://insidedisaster.com/haiti/about-thefilm>. Accessed on: Sept. 30, 2011.

The Haiti Earthquake. Simulation: Inside the Haiti Earthquake. Toronto, 2010b. Available at: <http://insidedisaster.com/haiti/ experience>. Accessed on: Sept. 3, 2011.

The Haiti Earthquake. Toronto, 2010c. Available at: <http:// insidedisaster.com/haiti/the-haiti-earthquake>. Accessed on: Sept. 1, 2011.

JENKINS, Henry. Convergence Culture: where old and new media collide. New York City: New York University Press, 2006. 336 p.

. Transmedia 202: Further Reflections. Confessions of an Aca-Fan. 
Los Angeles, 1 ago. 2011. Available at: <http://henryjenkins.org/2011/08/ defining_transmedia_further_re.html>. Accessed on: Sept. 25, 2011.

KOVACH, Bill; ROSENSTIEL, Tom. The Elements of Journalism: What Newspeople Should Know and the Public Should Expect. New York City: Three Rivers Press, 2007. 268 p.

MOLONEY, Kevin T. Porting Transmedia Storytelling to Journalism. 2011. 115 f. Dissertation (Master of Arts) - Faculty of Social Science, University of Denver, Denver, 2011.

NEGROPONTE, Nicholas. Being Digital. New York City: Vintage Books, 1996. 272 p.

NEWSGAMING.COM. Newsgaming. FAQ. Montevideo, [2003]. Available at: <http://www.newsgaming.com/faq.htm>. Accessed on: Jan. 15, 2012.

PRIMO, Alex. Quão interativo é o hipertexto?: Da interface potencial à escrita coletiva. Fronteiras: Estudos Midiáticos, São Leopoldo, v. 5, n. 2, p. 125-142, 2003.

QUINN, Stephen. What Is Convergence and How It Will Affect My Life? In: FILAK, Vincent F; QUINN, Stephen. Convergent Journalism, an Introduction. Oxford: Focal Press, 2005.

SANTAELLA, Lúcia. Navegar no ciberespaço: o perfil cognitivo do leitor imersivo. São Paulo: Paulus, 2007. 191 p.

SHIRKY, Clay. Here Comes Everybody: The Power of Organizing Without Organizations. New York City: Penguin Books, 2009. 352 p.

SOUZA, Maurício Dias. Jornalismo e Cultura da Convergência: a narrativa transmídia na cobertura do cablegate nos sites El País e Guardian. 2011. 252 f. Dissertação (Mestrado em Comunicação Midiática) - Programa de Pós-Graduação em Comunicação, Universidade Federal de Santa Maria, Santa Maria, 2011.

André Fagundes Pase is post-doctor from the Massachusetts Institute of Technology (MIT). Digital Communications Professor at Famecos-Pontifical Catholic University of Rio Grande do Sul (PUCRS), Brazil. E-mail: afpase@pucrs.br

Ana Cecília Bisso Nunes Nunes is a master Student in Social Communications at Famecos-PUCRS, Brazil, with a government scholarship (Capes/PROSUP). E-mail: nunes.anacecilia@gmail.com

Marcelo Crispim da Fontoura is a master Student in Social Communications at Famecos-PUCRS, Brazil, with a government scholarship (Capes/PROSUP). E-mail: fontoura_marcelo@hotmail.com 